
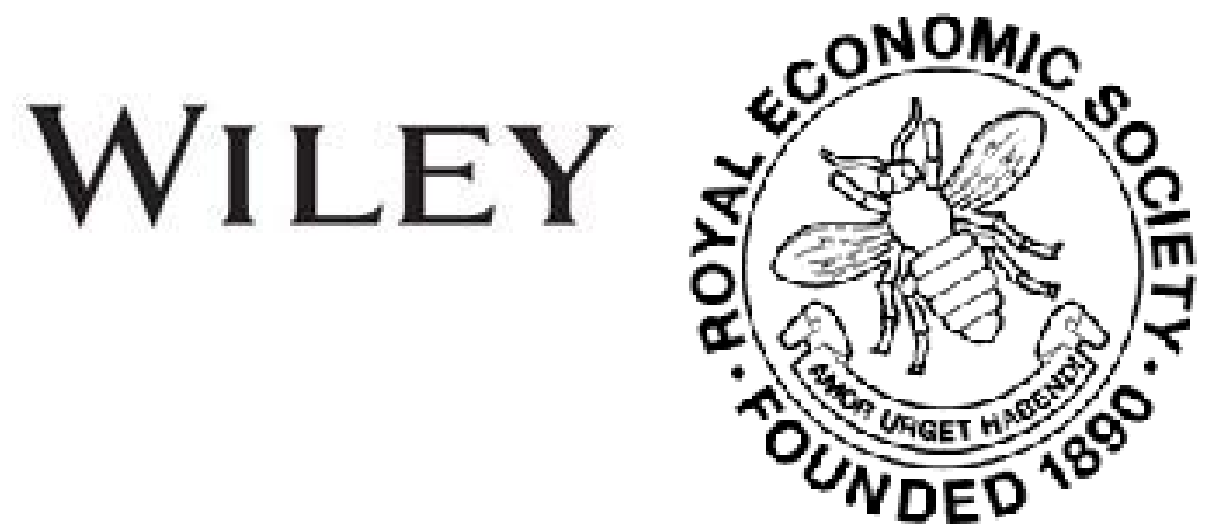

The Rise and Tendencies of German Transatlantic Enterprise Author(s): E. von Halle

Source: The Economic Journal, Vol. 17, No. 68 (Dec., 1907), pp. 490-503

Published by: Wiley on behalf of the Royal Economic Society

Stable URL: http://www.jstor.org/stable/2220850

Accessed: 24-06-2016 22:09 UTC

Your use of the JSTOR archive indicates your acceptance of the Terms \& Conditions of Use, available at

http://about.jstor.org/terms

JSTOR is a not-for-profit service that helps scholars, researchers, and students discover, use, and build upon a wide range of content in a trusted digital archive. We use information technology and tools to increase productivity and facilitate new forms of scholarship. For more information about JSTOR, please contact support@jstor.org.

Wiley, Royal Economic Society are collaborating with JSTOR to digitize, preserve and extend access to The Economic Journal 


\section{THE RISE AND TENDENCIES OF GERMAN}

\section{TRANSATLANTIC ENTERPRISE}

THE year 1907 is memorable as the Centennial of a change in the commercial relations between Germany and the United Kingdom. At the end of 1806 the members of the "Hamburg Court" of the English "Company of Merchant Adventurers" had been imprisoned by the French occupants. Seeing that the "Continental System" would not allow a continuation of their trade in 1807, they withdrew from Hamburg. This was the end of a settlement that had been established more than 200 years ago, after the decay of the Hanseatic League. It had played a most important part in transforming the character of the Anglo-German commerce, and whilst it had ceased to play an active rôle it had remained as a token of a most remarkable development.

Up to this time the trade relations of the German Empire, with the exception of a short period at the end of the eighteenth century, had been confined to European countries. Of its ocean commerce a very large part was handled by foreigners-English, Dutch, French, Scandinavians.

Before the establishment of the United States, a country without colonies had no lawful chance for transatlantic intercourse, and the small and powerless German territories could not take the risk of secretly entering into avenues which might have led them into serious conflicts with the strong colonial Powers.

The era of revolutionary wars consummated a most remarkable change; and by the last quinquennium of the eighteenth century the Hanse Towns, politically inoffensive in consequence of their smallness and neutrality, had become the chief marts for colonial wares, brought thither directly in foreign as well as in German bottoms. At the same time, the occupation of Amsterdam by the French and the suspension of cash payments by the Bank of England made Hamburg, with its famous bank, the centre of international exchanges. The residents of the small and conservative German harbour were surprised and somewhat overcome by the unexpected development, and by the sequence of 
a series of booms and crises which ensued between 1793 and 1806. The downfall of this year demonstrated the artificial character of this hot-house development; the Continental System and the blockade of the seven years preceding Napoleon's downfall put an almost complete stop to all kinds of maritime commerce on the German coast. The fear arose that even the old commercial position was lost for ever.

But as the former hopes, so now the present fears proved to be exaggerated. Slowly the wheels of commerce were started again after 1815, and it soon became apparent that some of the changes brought about by the turbulent period would prove to be permanently beneficial. The year 1808 had given independence to Brazil. Between 1810 and 1830 Spanish America won its freedom. This opened almost all of America to the free traffic of the world, and, full of new hope and enterprise, German merchants, especially of the Hanse Towns, were not slow to avail themselves of these opportunities.

Commercial firms emigrated to all countries of the Western Hemisphere. One hundred and eighty German firms alone were counted in the United States after 1840. Scores of them acquired an important position all the way from Mexico to Chile and the River La Plata. About this same time a number of German merchants gained a hand in the Eastern trade. The revocation of the monopoly of the East India Company in $\mathbf{1 8 1 5}$ had created limited opportunities for competition in its domain; in the 'twenties, German ships found access to the Chinese trade. A third important impetus ensued in the abolition of the colonial systems of almost all countries, following the English precedent at the middle of the century. The assertion of Soetbeer, the well-known economist, now covered the whole world: "Through the liberation of the larger part of America from colonial ties Germany, so to speak, was endowed with colonies, and Hamburg was now enabled to win an independent share in the world's commerce."

The American policy of reciprocity in shipping and the abrogation of navigation laws in the leading countries favoured still further the rise of shipping interests in some German States; their trade in the 'fifties extended to Australasia and along the African coast, so that before the establishment of the Empire there was to be found a certain amount of German trade with almost all countries of the world.

It was not German traffic though; there was not a German flag; it was carried on under the respective flags of Hamburg, 
Bremen, Lübeck, Prussia, Mecklenburg, Oldenburg, and Hanover, \&c., until, in 1867, these were replaced by the ensign of the North German Union and by the flag of the German Empire in 1871. Moreover, the trade was not completely German. German firms, established abroad, transacted a large percentage of their business, not with Germany, but with other countries; for instance, German houses sent coffee from Brazil to New York or Havre and supplied the Brazilian market with cottons from Manchester, silks from Lyons, cutlery from Sheffield, and matches from Sweden. And, further, it was not wholly German in this respect, that a large share of the business was carried on with foreign banking facilities, under foreign insurance, and, to a great extent, in foreign bottoms.

Germans from various German States were thus busy traders over the world, but they represented, more or less, local interests ; they were not agents of a national trade, as there was not a German nation to represent; they were not representatives of large exporting industries, as there were practically no large industries with strong exporting interests, with the possible exception of the old-established and powerful linen industry. Germany was an exporter of agricultural products which went chiefly to England from the Baltic ports of Prussia. Exports of manufactured articles were very limited. Of the latter, a considerable share went to the transatlantic countries through England, which also was the first hand and medium for a large part of Germany's imports of tropical and sub-tropical products.

Nevertheless, it would be a mistake to underrate the fact that hundreds of German merchants and bankers thrived in transatlantic countries, and that the Germans had become accustomed to send their ships regularly to the farthest parts of the world. "Without the old foundation, laid chiefly under Hanseatic flags," says an article in the thirteenth volume of the publications of the Hamburg Geographical Society, "Germany would not possess to-day the transoceanic trade which she now has."

The eighth decade of the nineteenth century marks the turning-point not only in German political history, but also in the economie development of the country. What was initiated by the Zollverein in $\mathbf{1 8 3 4}$ on economic lines, a national union, was now politically consummated. The re-occupation of two lost provinces from France strengthened the economic activities of the new Empire. At about this same time the country reached a point in the growth of its population that was not less momentous than these events. At the beginning of the century there lived 
on the soil of the present Empire little more than twenty million people. In 1871 their number increased to about forty-one millions. This was a stage of saturation that, a generation ago, Friedrich List had pointed out as the possible limit of density of population for a self-sustaining Germany. The further increase at once led to its transition from a grain-exporting to a grainimporting country. This was a landmark in Germany's foreign situation. From this time Germany had but to choose between the importation of food-stuffs and other necessities, or the exportation of hundreds of thousands of her people. Whilst emigration for a time seemed to bid fair to assist in the solution of the problem, it reached its height with more than 220,000 emigrants in 1882, and has fallen off ever since. It runs between 20,000 and 40,000 a year at present. On the other hand, there has been an ever-increasing excess of agricultural importations, and to-day 20 per cent. of the population of the country feed on foreign-grown food-stuffs, whilst more than 90 per cent. of the raw material for clothing comes from abroad, and an increasing number of imported "stimulants" which have in former times been considered as luxuries have now become goods of regular consumption by the masses, risen gradually to a higher standard of life.

Whilst in England at the end of the eighteenth or early in the nineteenth century the engine of capitalistic enterprise was started by the entrepreneur, who desired to make England the chief exporter of the world, to establish the wealth and power of his social class; whilst it was the exporting interest that transformed the social fabric of England and enabled the country to support a rapidly rising population: it was the importing interests of Germany, the necessity of feeding and employing a grown population, which compelled Germany to intensify her foreign activities. It took more than twenty years for the world, yes, even for Germany herself, to realise the meaning of the change. Never before had the interior and southern parts of the country known what " sea interests" could mean for them. One had been accustomed to consider transoceanic enterprise as the private domain of the sea-coast population who were looked at as half foreigners -English agents with an un-German mercantile spirit, difficult to classify in the hierarchy of civil and military interests. Now the people at large became aware that the cotton crops of North America, India, and Egypt, the wheat, maize, and rice supply of these countries, of Russia, the Argentine Republic, \&c., the commercial situation in America or Australia, and the resulting demand for steel and hardware, textiles and chemicals, had an immediate 
effect upon the well-being of the inhabitants of Stuttgart and München, Liepzig and Nürnberg, Breslau and Essen; and the looks of transatlantic crops and international markets could exercise a stronger influence upon the economic good of German working-men and manufacturers than the look of their Grand Duke or local administrative authority.

The development itself has in no sense been artificial, nor the product of governmental interference, as has been often stated abroad. Up to a very recent date the great majority of German officials, trained in the views of a provincial or continental standpoint, have looked upon the new development with a spirit of dissatisfaction, if not suspicion. Seafaring interests were something too antagonistic to their beloved methods of local regulation; and still to-day there are lively complaints going on amongst merchants and manufacturers that their interests are not properly cherished by certain classes of governmental officials. The German Empire has neither an independent Board of Trade nor a Ministry of Commerce and Navigation. Increasing attacks are directed by importers and exporters against its consular service; and the methods are vigorously denounced by which officials are trained for positions concerned with industrial and mercantile questions. It is the spread of the mercantile spirit of the coasting districts, imported, I dare say, to a large extent from England, and raised to a high standard by its touch with the achievements of German technological science and training, that has produced new types and classes of "captains of industry," merchant princes, and leaders of powerful stock companies who are able to handle the great volume of modern German trade.

The German nation is very young and unaccustomed to judge questions of international and inter-continental bearing. It was a difficult task to educate it to a realisation of the fact that its inner and the external situation were undergoing a rapid change. Strong and powerful words have been used, after the fashion, by the way, of English and American political campaigns, to bring about the necessary transformation of thinking.

During the first thirty-five years of its existence the foreign commerce of the Empire rose from $£ 300,000,000$ in 1872 to nearly $£ 750,000,000$ in 1906 . Imports increased from $£ 175,000,000$ to $£ 425,000,000$, and exports from $£ 125,000,000$ to $£ 325,000,000$ This means an increase in foreign trade of 150 per cent., whilst the population has risen during the same period by $20,750,000$, i.e., less than 50 per cent. Foreign commerce, there- 
fore, means something different to the Germany of to-day from what it did before the establishment of the Empire.

In this same time the steamers of the "commercial fleet" of the Empire rose from 100,000 to $1,900,000$ tons, whilst the sailing ships decreased from 900,000 to less than 500,000 tons, so that the carrying capacity was increased from $1,200,000$ to more than $8,000,000$ tons. Of the German foreign commerce an increasing share, as is quite natural, is maritime commerce. Threefourths of the imports come and two-thirds go by sea, and of these an increasing part is transacted with foreign continents. These, in 1906, sent $£ 160,000,000$ of merchandise as compared with $£ 240,000,000$, from Europe, and received $£ 87,500,000$ compared with $£ 233,300,000$ taken up by Europe.

The German balance of trade has become increasingly negative; whilst the difference amounted to $£ 50,000,000$ half a generation ago, it has risen to $£ 100,000,000$ to-day, and it rests almost entirely upon the differences in the trade with foreign continents that supply food-stuffs and raw materials. To English readers it is quite plain how this difference may be made up. It is by the income from foreign shipping, insurance, banking, and investments in foreign enterprise and foreign stocks and bonds. Recent investigations have shown that, whilst perhaps $£ 20,000,000$ are derived from shipping, the rest of the negative balance is made up by income from investments abroad that are figured at something like $1 \frac{1}{2}$ milliard pounds. A careful review seems to prove that whilst the valuation of German colonial enterprise at the present hour cannot yet be put higher than $£ 50,000,000$, investments in the bonds and stocks of foreign transoceanic countries, including Turkey, amount to $£ 200,000,000$ out of a total of $£ 800,000,000$ of German foreign investments in securities; whilst the value of the property of German citizens living abroad and German investments in transoceanic undertakings, including Turkey, may be put at about $£ 450,000,000$. The total of investments in foreign continents represents the smaller half, but no doubt the most productive part of German foreign investments. Without this and the chances for its extension, Germany could not hope to support her congested population within her present boundaries without a disturbance of either the social peace within or the international political peace.

The number of Germans in foreign countries, outside of the United States and Australia, who have preserved their citizenship may be put at 500,000. Of these less than 75,000 to 80,000 
live in transoceanic countries-small figures compared with the fact that the number of emigrants lost by Germany during the nineteenth century, with their descendants, amounts to not less than 25,000,000. This would seem a fatarl loss but for the fact that the remaining population of the country has, nevertheless, increased during the century from $20,000,000$ to more than $60,000,000$. On the other hand, valuable connections have been preserved by emigrants with the mother country, and the proceeds of the income of the work of Germans abroad form a most valuable contribution to the national income.

It is worth while to look at the position which the British Empire holds in Germany's outdoor traffic. A considerable change has, no doubt, taken place. The position formerly held by England as the exporter of raw products from, and the importer of manufactured articles into Germany, as the chief middleman and carrier of her transatlantic trade, and as her banker and moneylender, does not exist any longer. To a considerable extent German transatlantic commerce has become independent of the services of the middleman. This is the same phenomenon which in many instances to-day connects the manufacturer in the interior towns of England or Germany with the transatlantic producer and consumer directly, with the cutting out of the middleman in Liverpool or Hamburg and in transatlantic seaports. The increasing capital in the hands of German bankers has in many cases enabled her merchants to dispense with foreign credits. There are times now when more German capital seeks employment in the London markets than English credit is bid for by German tradesmen.

Large amounts of high-grade manufactured goods still go from English centres of industry to Germany, but a large share of her British imports to-day consists of half-finished goods and raw materials, and from Greater Britain she receives imports of the same character and food-stuffs, whilst her exports to the British Empire are composed of raw materials, half-finished goods, and manufactures.

The British Empire is no longer paramount, yet it leads in German commerce to-day as ever, in spite of all these changes. In 1906 it supplied more than 18 per cent. of German imports, $£ 74,000,000$, of which $£ 41,000,000$ came from the British Isles, whilst it took a little over 20 per cent. of German exports, namely, $£ 65,000,000$, of which $£ 53,000,000$ went to the British Isles. It is characteristic that Germany sent an excess of $£ 12,000,000$ to England, whilst she received an excess of 
$£ 21,000,000$ from British colonies. The German balance of trade is positive with the British Isles; it is negative with the whole of the British Empire.

The whole development seems to show that in more than one respect, on the ocean of modern economic conditions, England and Germany are sailing in the same boat. This explains why many of their interests lie in the same direction, whilst there may be sometimes a certain antagonism as to the position they hold in respect to the accommodation available in this vessel. Both have to supply an increasing population with material for work and food, partly obtained through imports, and have to pay with the results of the labour of their citizens, partly in the form of exports of merchandise, partly through the proceeds of former exports invested abroad. It would seem to be a comparatively simple matter when comparing the size of the world with England and Germany and their populations respectively, but for the fact that a majority of the imports required by each of them belong to the domain of decreasing returns, whilst a majority of their exports come from the domain of increasing returns. Considering the fact that other countries, such as Belgium, Holland, Japan, and sometimes France, live in a somewhat similar state to these two countries, and that the United States ere long will also start a policy of heavy industrial exports, and considering further that many other countries to-day, even tropical and sub-tropical States, are trying to establish modern industries of their own and profess their intention to manufacture at home their raw materials, the forecast of the future becomes complicated. German economic thought of late has, in consequence of these considerations, paid more attention to the question of foreign investments, as it will prove more and more difficult to find an adequate outlet for certain exports of internationally competing industries.

I do not need to discuss here the standpoint taken by English economists in regard to their similar problems. The question of international competition in exports is surely an important one between certain industries of the two countries. It will become much more important, though, in respect to the rising industries of other, chiefly the transatlantic countries. On the theory of the case we have quite a number of learned contributions on either side in Germany, by Oldenberg, Wagner, Pohle, Evert, Dietzel, Huber, Gothein, \&c. The problems involved surely offer the perspective for the whole industrial situation of the twenty-first 
century world. I shall attempt to show, though, that for Germany only part of her problems are transoceanic; whilst another large part will always be continental. For England all commerce is transoceanic and must become increasingly so. For Germany an extended transatlantic commerce is vital, but $£ 155,000,000$, about 40 per cent. of her imports, come from, and $£ 138,000,000$, more than 40 per cent. of her exports, go to her immediate neighbours on the Continent. Her capital investments on the Continent are larger than over the seas$£ 300,000,000$ or more in Russia alone. One centre of her commercial policy must always lie near the continental problems; her geographical situation compels her to face continental neighbours on three sides of her boundaries and the sea on the fourth.

As we have seen, in Germany's maritime commercial relations, the British Empire ranks foremost. It is further to be noticed that the three foremost commercial Powers of the worldEngland, Germany, and the United States-are at the same time the largest suppliers to and the best customers of each other. This shows more plainly still how the nations are in the same boat.

The mutual trade represents an overwhelming interest; it may be added that the internal well-being of each nation is most important for the others in consequence of modern industrial conditions. A flourishing home market means power of consumption. A depression necessarily means the throwing of industrial products on the world's markets. This is one of the intrinsics of machine production. A crisis in the United States would mean a double bar to German transatlantic enterprise by narrowing the markets in the great Republic and increasing American competition in South America and Eastern Asia, if not in Europe itself. A breakdown of American prosperity might bring American steel to Essen and Solingen and American coal to Newcastle.

I trust I have explained how the development of German maritime enterprise over the seas was the product of natural tendencies, of questions of population, and the social well-being of the masses; it was not the consequence of artificial interference or of unsound thirst for adventure. It remains to say a few words about the special methods that prevail at present.

We very often are told that besides governmental assistance, advice and even interference, the rise of this new notion of " sea interests" is due to the protective tariff, the Government railways, shipping subsidies, and that special form of trusts called "Kartells."

As to the tariff, I beg most emphatically to disagree with the 
view that this is entirely useful to-day for German transatlantic enterprise. I am not a free trader, and I was able to convince myself that protection twenty-five years ago did much to nourish weak infant industries. But as conditions stand to-day many German industries could do much better if free trade prevailed. They could hold their own at home and export more cheaply but for the needs of agricultural protection for the country. An abolition of agricultural protection would most seriously interfere with the well-being of German agriculture and the agricultural population, which to-day still counts in its ranks more than $20,000,000$ people, and so it would directly hurt the population at large. It would not only damage the consumptive capacity of millions, but would quickly bring the country to a situation where it would have to fall back on gigantic agricultural imports. This, again, for the continental country would bring about a much unsafer situation than for England, with her avenues of commerce ever open under the protection of her fleet.

Agricultural protection from the standpoint of transatlantic interest is an unavoidable evil that carries in its train the continuation of a moderate industrial protection.

As to transportation, Germany, no doubt, has a good and effective system of railways and waterways. Manufacturers and exporters, though accustomed to complain wherever it is possible, will usually admit that it is decently managed. They have been greatly assisted, too, by the existence of good navigable waterways like the waterways of the Rhine, Weser, Elbe, Oder, \&c., that go down from the industrial centres to the sea, and which have taken a prominent part in keeping the railway rates down. The general statement that German rates to the sea-coast are specially arranged for the pushing of exports very often leaves this fact out of consideration, and, besides, it mistakes for a promotion of the exporting interest those tendencies which aim only to lead German exports to German seaports instead of to the outlying foreign harbours of Antwerp and Rotterdam on the Scheld and Rhine. I may add it would surely seem to be a most redeeming feature of European life if a state-railway system, burdened with all the red-tape of bureaucratic management, were able to make its arrangements more beneficial to the trade of its country than the privately managed railway systems of America and England, and, nevertheless, earn a respectable and increasing surplus on the investment every year.

As to German shipping, considerable in itself, though small as compared with the still five times larger fleet of England, it No. 68.-VoL. XVII. N N 
may be noticed that this brings us nearer the real points. All German shipping is private enterprise. Only for the service to the Far East and Africa do German companies receive postal subsidies; one of them, the North German Lloyd, claims that even this has been a doubtful present. All the rest has been developed independently by the sons of the Hanse Towns. Surely this is an evidence of a special talent at organisation proved centuries ago in the Hanseatic League, suppressed systematically for centuries by the political decadence of the old Empire, but not killed. It now has witnessed a revival.

And this leads to the last point-the question of organisation at large. A careful review of the activities of German enterprise over the seas will show its predominating importance. It is not through the agencies of the German Kartells that foreign enterprise rose or flourishes to-day. They have done much to strengthen German industry within the country. Some of them have attempted to develop an exporting policy, but for the large majority all interest centres almost absolutely on the internal market, and even to the rest exportation is only a side issue. As history shows, transatlantic enterprise was built up by individual merchants and exporting manufacturers. A few representatives of Kartells recently began to appear in foreign countries.

Professor Sombart and myself, upon careful investigation at the end of the nineties, found independently that the internal market had developed much more rapidly than exports in Germany, and the same tendency still obtains. No doubt, in times of crises Kartells will " dump" ; but they will do this not more, and in normal times will do it less than any large manufacturer who needs a quick realisation of his stock on hand. It may be different with a "trust" which can develop a more uniform policy of sales, but to this state very few German industries have risen.

It is a well-known fact that manufacturers who have the safety of selling a certain amount at home at remunerative prices avail themselves of the freedom of exporting a surplus as cheaply as possible. Evidences of this are neither novel nor peculiar to Germany, but are well-known emanations of modern machineproduced economic conditions.

But in two respects surely German talent of organisation has helped a good deal to pull up in the great international race. On the one hand the training in well-organised action given in the schools, the army, the technological schools, \&c., of the country 
has proved very helpful; though this also carries with it some dangers wherever individual activity is essential to foreign success. On the other hand, great assistance has been given in recent years to an extension of capitalistic enterprise by the extension of concentration in banking that has enabled the German business world to give a quicker rotation to its capital, small as this may be compared to the per capita wealth of England and France. Here, too, it is surely not Government assistance that has brought about the result; it is a well-known fact that the mistaken "Börsengesetz" has created general hostility among the banking fraternity, who justly claim that it direfully interferes with the sound development of the German money market at large, and especially with the foreign department of our Stock Exchanges. This law was a product of that governmentalism and agrarian hostility against capitalism and oceanic commerce which I mentioned before. From this source sprang a method of taxation of Stock Exchange transactions and securities that has kept many foreign securities out of German markets. Those that had lost money in foreign investments cried fraud; those that had made money wisely held their tongues. The situation was made use of by such as did not want to see foreign capitalistic interests grow too strong. The result was not in every respect quite what was expected. The strengthening of the strongest and most concentrated financial bodies, the large banks, could not be checked. They were able to swallow smaller interests and then to lend their assistance to the promotion of foreign enterprise. The old German private banker was swallowed up by large concerns, and this extended to German bankers abroad-German bankers in transatlantic places awoke to find at their door a branch of one of the ten or eleven German transatlantic banks which, on their part, are organs of the large German home banks in Berlin. They had to choose between a fierce competition against many odds, and complete submission, which ended in absorption or the re-modelling of their business into an agency of Central Banks. In this line also Germany has not reached by a long way what English foreign and colonial banks were able to obtain, but it has been a most useful help to German capitalistic growth nevertheless.

To sum the whole argument: Germany has developed considerable interests beyond the seas. They are vital for the preservation of the home status. She has been able to build them up with the help of her good schools and scientific institutions, 
enterprising sons, a good talent for industrial organisation at home, and a good system of transportation there and abroad. We may add a talent for languages and adaptation to the habits and wants of foreign countries, a re-awakening of the adventurous spirit of the seafaring sons of the Hanseatic League. And we may further add a removal of many of the hindrances that the political disunion and an unfortunate system of territorial government had for centuries thrown in the way of all attempts at an economic revival. The year 1871 brought, with the establishment of the Empire, a political system more appropriate to the requirements of modern economic structure.

It has been more by the removal of a number of hindrances than by positive assistance from the Government that the present position in international enterprise has been attained. Practical men were not led into this by fantastic ideas of world power, but by plain considerations of the economic and social requirements of the resurrected nation. It ought to be noticed that all these interests are considerable to-day; nevertheless, they are widely surpassed by England. They have been much spoken of within the last twenty years, because in many regions they represented something novel, and parties that were met by their competition cried out against them, whilst those to whom their appearance proved useful remained quiet. When, in Germany, a political compaign was started to turn the people's attention towards these new interests, they were shown to them, of course, through a magnifying glass; and the world or the competitors pretended to believe this to be the real size of the picture. Germany had to make up something on the ocean, and, I think, she has done it in a measure nearly sufficient to the requirements of her economic condition. If she can feel sure of that final basis of Pitt's statesmanship-safety - she has attained a state of relative saturation in maritime matters; i.e., there is no reason why in commerce or shipping or transatlantic investments she should proceed more rapidly than England.

Germany has a future on the water, and she must have it for the reasons which I have elaborated. This future and her coast-line must be protected and kept open, and, therefore, she had to establish that insurance institution for marine values-a strong fleet. But her geographical situation will, under the assumption that she is safe in this one vital respect, always put before her a number of other questions of a no less vital character. Germany is surrounded by other countries with a 
dense population, the majority of them different in nationality. Whilst in the South France has lost a good deal of her aggressiveness in consequence of the retarding increase in her population, in the East a strong pressure has risen from the Polish quarters, a revival of the almost never-ceasing tendencies of " migration to the West" that has filled the history of the last sixteen centuries. The fact is most momentous, that not beyond the frontiers, but in Prussia, the Polish question lifts its head and Slavic tribes attempt to reconquer the old settled German soil of Silesia; yes, even the two provinces of Prussia and parts of Pomerania. Whilst hundreds of thousands of emigrants have left Germany for over-sea lands, tens of thousands of Polish agricultural labourers must be imported yearly to do the work on the estates and farms of Eastern and Central Germany. The rise of the Slavic wave is also proved by the fact that thousands of the inhabitants of old German settlements in Russia remigrate to and through their forefathers' country. These and some other considerations will require the most careful treatment of Eastern frontier questions by German statesmen in the immediate future; and for generations to come it will require all the national energy and power of population of the people of Germany to stem that tide.

Germany must attempt to increase her transatlantic enterprise normally, to develop the productiveness of her colonies along the lines of tropical and sub-tropical raw production, and the searching for mining treasures, and the consumptive capacity of the native inhabitants. She must show the flag of her merchantmen in all ports of the globe, and must be able to protect it as well as the population of her coasts. But the policy of Germany will for ever be primarily connected with continental issues. Only with the assistance of her sea interests will she be able to support herself and follow her vocation; the innermost destiny of the country, though, will always be interwoven with continental problems.

E. VON HALLE 